\title{
EL "MAL CONTABLE" EN COLOMBIA: DESCRIPCIÓN DE LAS CONDUCTAS SANCIONADAS POR LA JUNTA CENTRAL DE CONTADORES (2010-2017)
}

\section{THE "ACCOUNTING EVIL" IN COLOMBIA: DESCRIPTION OF THE BEHAVIORS SANCTIONED BY THE JUNTA CENTRAL DE CONTADORES (2010-2017)}

\author{
Sergio Luis Ordóñez Noreña'
}

\section{RESUMEN}

Se responde a la pregunta: ¿cuál o cuáles son las conductas que con mayor frecuencia sancionó la Junta Central de Contadores entre el periodo 2010-2017? Describir una conducta sancionada supone establecer relaciones entre el comportamiento infractor, la sanción, el tiempo de esta, el tipo de falta y los artículos del código de ética profesional que se infringen. Se pretende prevenir a los profesionales en ejercicio y formación para que eviten este tipo de comportamientos y conozcan sus consecuencias. También, caracterizar de forma aproximada imágenes sobre el mal contable en Colombia que permitan dinamizar la forma cómo abordamos la formación en ética profesional del contador público.
Palabras clave: código de ética, sanción, esquemas, imágenes, comportamiento.

\section{ABSTRACT}

The question is answered: What are the behaviors that were most frequently sanctioned by the Junta Central de Contadores between 2010 and 2017? Describing a sanctioned conduct involves establishing relationships between the offending behavior, the sanction, the time of the sanction, the type of misconduct and the items of the professional code of ethics that are infringed. The aim is to warn professionals in practice and in training to avoid this type of behavior and to be aware of its consequences. Also, to characterize in an approximate way images on the

1 Docente del programa de Contaduría Pública de la Fundación Universitaria Los Libertadores. Colombia.

Correo electrónico: serluon@gmail.com

Orcid: https://orcid.org/0000-0002-5614-1860

Código JEL: M49.

Fecha de recepción: 13/08/2018

Fecha de aceptación: 19/09/2018

DOI: https://doi.org/10.18601/16577175.n22.05 
bad accounting in Colombia that allow to dynamize the way we approach the formation in professional ethics of the Public Accountant.

Keywords: code of ethics, sanction, schemes, images, behavior.

\section{INTRODUCCIÓN}

La profesión de la contaduría pública en Colombia se encuentra reglamentada por la Ley 43 de 1990, en ella se indican las razones por las cuales un contador público puede ser sancionado cuando falta con su conducta al código de ética profesional que dicha ley incluye. Las sanciones que impone la Junta Central de Contadores Públicos pueden ser: amonestación, multa, suspensión y cancelación de la tarjeta profesional. Se espera del contador público un comportamiento basado en principios del código de ética profesional que, entre otros, exigen de él, integridad, objetividad, independencia, responsabilidad, y en caso de faltar a ellos procede la sanción a su conducta ${ }^{2}$.

En algunas situaciones la conducta del contador público infringe el código de ética profesional, afectando la fe pública, los principios éticos e inobservando normas que debe cumplir en su ejercicio profesional, entre otros motivos. De este modo, la sociedad y diferentes agentes con interés económico pierden la confianza en la profesión de la contaduría pública ${ }^{3}$.

Resulta conveniente, entonces, reconocer cuál o cuáles son las conductas profesionales que con mayor frecuencia infringen el código de ética de la contaduría pública según las sanciones impuestas por la Junta Central de Contadores Públicos entre el periodo 2010- 2017 $7^{[4]}$.

Para ello, se procede a identificar el tipo de conducta más sancionada, la sanción más impuesta, el tipo de falta y los artí-

2 La normatividad que regula el código de ética profesional se compone del capítulo 4, título primero a sexto de la Ley 43 de 1990, y del Código de ética para profesionales de la Contabilidad emitido por el Consejo de Normas Internacionales de Ética para contadores (IESBA) (2014), que adicionó el decreto 302 de 2015.

3 García (2003), Ochoa, Zamarra, Guevara (2011), Nieto (2017) y Universidad Libre (2018). Algunos autores han investigado la conducta profesional de contadores y auditores en escándalos financieros de carácter nacional e internacional, coinciden en la importancia de recuperar la confianza y credibilidad en la profesión contable. Un reciente informe anunciado por la Universidad Libre llama la atención sobre conductas de contadores públicos asociadas con corrupción e irregularidades. Resulta importante examinar con detalle las conductas sancionadas e identificar posibles caminos de acción que permitan reconducir la formación profesional en ética y de algún modo mejorar dichos comportamientos.

4 El presidente del tribunal disciplinario de la Junta Central de Contadores presentó un informe de gestión que comprende el periodo abril 2016 a mayo 2017; en este periodo se impusieron 151 sanciones y estas fueron las cinco conductas más sancionadas: 1) Certificar información contraria a la realidad, 94 casos $(62 \%), 2)$ Violación al régimen de inhabilidades, incompatibilidades, conflicto de interés, $16(10 \%), 3)$ Retención indebida de documentos e información contable, $12(8 \%), 4)$ Contar con más de 3 sanciones debidamente ejecutoriadas, 8 (5\%), 5) 
culos del código de ética que con dicho comportamiento se afectan. La JCC publica en su página web las sanciones impuestas a contadores públicos y con dicho insumo se procede a desagregar las variables de información que permitan establecer relaciones entre conducta, sanción, falta, tiempo y código de ética profesional.

Del análisis y descripción de las sanciones impuestas en ocho años se espera obtener la o las conductas que pueden llegar a configurar aquello que hacen mal los contadores públicos en Colombia.

Los resultados de este análisis descriptivo se acompañan de dos insumos didácticos, el primero consiste en el desarrollo de esquemas normativos para el aprendizaje del código de ética profesional, y, el segundo, en el desarrollo de imágenes del mal contable, dicha imagen representa la conducta sancionada y aunado a los esquemas normativos pueden servir de insumo para reconocer aquellas conductas que deberían evitarse en el ejercicio profesional. Este documento se estructura alrededor de tres ejes: las conductas sancionadas, los esquemas normativos y las imágenes del mal contable en Colombia.

\section{MATERIALES Y MÉTODOS}

Para el desarrollo de este análisis descriptivo se siguió el siguiente orden:

\section{Las sanciones impuestas por la junta}

Obtención de las sanciones emitidas por la Junta Central de Contadores Públicos entre el periodo 2010-2017, dicha información se encuentra publicada en la página web de la junta y se presenta a continuación (imagen 1).

Imagen 1.

Ejemplo de una conducta sancionada

C (i) No es seguro | sgr.jccgor.c0:8080/apexf?p=119:1:0

LUIS ALFREDO MEDINAMESA 79106074 CONTADOR AMONESTACIÓN (meses) 01/06/2017 11708/2017 Ocultar_Conducta CONDUCTA

El comportamiento que vulnera la ética profesional, desplegado por el investigado se puede calficar como LEVE, dado que con la conducta reprochada al profesional no se ve demostrado que se hubiese causado danos y perjuicios consistentes en multas y/o sanciones al usuario de sus servicios, ya titulo de CULPA, en virtud del conocimiento de la actividad contable que presupone un actuar conforme a las normas vigentes, sin embargo, amén de su conocimiento desatendió su deber profesional como contador, pues no fue diligente en la devolución de la información contable perteneciente al usuario de sus servicios, vulnerando presuntamente los artículos 8,37.4, 37.6 de la Ley 43 de 1990

Fuente: página web de la JCC.

Infringir principios de contabilidad generalmente aceptados, 4 (3\%) (JCC, 2018, 2017, Molano, 2017). Esta información presenta una conducta y su frecuencia en una población que la infringe en un periodo de tiempo, sin embargo, no establece relaciones entre variables que permitan reconocer cómo impacta la conducta sancionada en el tipo de sanción, tipo de falta y artículos del código de ética infringidos. El trabajo de investigación descriptivo que aquí se presentan pretende establecer esas relaciones 
La sanción presenta información separada en el encabezado de esta y una descripción de la conducta sancionada en el campo "conducta". De la información separada se tomó: el género del implicado, el cargo, el tipo de sanción y las fechas de resolución y ejecución.

Como se puede observar el campo "conducta" es el más relevante, porque en este se indica el comportamiento infractor, sus características, el tipo de falta y los artículos del código de ética infringidos. Sin embargo, la redacción de esta conducta une en un mismo texto situaciones de naturaleza distinta, como nombre del implicado, cargo, nombre de la empresa, situación o falta que se comete y normas que se infringen. Por tal motivo, se procede a desagregar la información en una matriz que permita aislar las variables.

\section{El diligenciamiento de una matriz} para el análisis descriptivo de las sanciones La matriz incluye los siguientes campos: número, género, cargo, fecha de resolución, fecha de ejecución, con- ducta según JCC, sanción, tiempo, tipo de falta, tipificación de la conducta, cada uno de los artículos del código de ética profesional, es decir, 35, 36, 37.1 a 71.

De los campos de la matriz es importante indicar que para cuantificar los artículos del código de ética infringidos por cada sanción, se usó el número 1 para verdadero y el número 0 para falso.

El campo "tipificación de la conducta" es, tal vez, el más significativo de la matriz, porque establece el comportamiento infractor y permite luego agrupar las frecuencias de estos. Para su redacción se utilizaron verbos que permitieron indicar el comportamiento sancionado. En algunos casos fue sencillo identificar y establecer dicha conducta y aislarla del cuadro de la sanción que publica la junta, en otros casos fue necesario establecerla.

Así, tabuladas las variables, a continuación, se presenta un ejemplo de la matriz y su desarrollo:

Matriz 1. Análisis de las conductas sancionadas por la JCC

\begin{tabular}{|l|l|l|l|}
\hline \multicolumn{1}{|c|}{ 1. Número } & \multicolumn{1}{|c|}{ 2. Género } & \multicolumn{1}{c|}{ 3. Resolución } & 4. Ejecución \\
\hline 16 & Contador & $18 / 05 / 2017$ & $27 / 12 / 2017$ \\
\hline
\end{tabular}

\begin{tabular}{|c|c|c|}
\hline 5. Conducta & 6. Sanción & 7. Tiempo \\
\hline $\begin{array}{l}\text { El comportamiento que vulnera la ética profesional, } \\
\text { desplegado por el investigado se puede calificar como } \\
\text { grave, dadas las modalidades y circunstancias en las que } \\
\text { se cometió la falta, que se aprecian teniendo en cuenta } \\
\text { la desatención empleada por la profesional dado que no } \\
\text { cumplió con las funciones propias de su cargo y, a su vez, } \\
\text { no realizo la devolución de los soportes contables, dejan- } \\
\text { do en desconocimiento al usuario de sus servicios de su } \\
\text { situación financiera y contable, y sin la posibilidad de que } \\
\text { esta fuera emitida al no contar con los soportes, y a título }\end{array}$ & Suspensión & 9 \\
\hline
\end{tabular}




\begin{tabular}{|l|l|l|}
\hline 5. Conducta & 6. Sanción & 7. Tiempo \\
\hline $\begin{array}{l}\text { de culpa dada la presunta falta de diligencia y cuidado en el } \\
\text { ejercicio de su profesión, sometiendo a riesgos injustificados } \\
\text { a los usuarios de sus servicios profesionales, vulnerando } \\
\text { presuntamente los artículos 8, 10,37.4, 37.6 y 45 de la Ley } \\
43 \text { de 1990. }\end{array}$ & & \\
\hline
\end{tabular}

\begin{tabular}{|c|c|}
\hline 8. Tipo de falta & 9. Tipificación de la conducta \\
\hline Grave a título de culpa & $\begin{array}{c}\text { Retener injustificadamente información contable a uno de los } \\
\text { usuarios de sus servicios. }\end{array}$ \\
\hline
\end{tabular}

\begin{tabular}{|c|c|c|}
\hline 37. 4. Responsabilidad & $\begin{array}{c}\text { 37.6. Observancia de las } \\
\text { normas }\end{array}$ & 45. Riesgos injustificados \\
\hline 1 & 1 & 1 \\
\hline
\end{tabular}

Fuente: elaboración propia.

Para cada conducta sancionada se procedió del mismo modo. Se examinaron un total de 559 situaciones entre los años 2010 a 2017. Con este procedimiento se permite obtener la conducta tipificada según su frecuencia o el número de veces que se repitió dicha conducta, el tipo de sanción que más se impone, la falta y el tiempo de sanción asociado con el tipo de falta. De igual modo, una vez se separan las variables de análisis se procedió a realizar relaciones entre variables.

\section{Análisis de resultados y tipificación de estos}

a. Se usaron las características de Excel para el análisis de variables individuales, por ejemplo, el tipo de sanción que más se impuso.

b. Se usaron las características de Excel para establecer y graficar las siguientes relaciones entre las cinco conductas frecuentemente más sancionadas:

i. Conducta sancionada, sanción, tipo de falta y tiempo de la sanción. ii. Conducta sancionada, sanción y artículos más infringidos.

c. Se usaron gráficos de araña para representar atributos de las conductas y compararlos entre las cinco más sancionadas.

4. El uso de esquemas normativos para el aprendizaje del código de ética profesional del contador público

Por esquema normativo se estipula una representación gráfica de la norma, para su desarrollo se utilizan convenciones que permiten simplificar el proceso de aprendizaje normativo y sustituyen la memorización por la creación o dibujo de una imagen. Dichos esquemas permiten explicitar atributos normativos de prohibición, obligación y permiso o excepción. Se considera que representan el código normativo y se leen de izquierda a derecha mediante la relación de sus símbolos. Se anexa un listado de pasos para su elaboración.

5. Las imágenes del mal contable en Colombia 
Una vez se establecieron las cinco conductas más sancionadas por la JCC, se procedió a crear imágenes de dichas conductas, concretamente se dibujaron a contadores públicos infringiendo el código de ética profesional. Dichos dibujos surgieron en la dinámica de la cátedra de ética itinerante que desarrollan las universidades que hacen pare de la red para la formación en revisoría fiscal. En una de las sesiones de la cátedra se presentaron avances de este trabajo y se les solicitó a los estudiantes que realizaran dibujos del mal contable en Colombia 5 .

\section{RESULTADOS Y DISCUSIÓN}

A continuación, se presentan cuatro resultados en el siguiente orden: 1) caracterización del mal contable en Colombia según las sanciones impuestas por la JCC entre los años 2010 a 2017; 2) esquemas normativos para el aprendizaje del código de ética profesional; 3) imágenes del mal contable en Colombia, y, 4) insumo didáctico para el reconocimiento de las conductas sancionadas.

Caracterización del mal contable en Colombia según las sanciones impuestas por la Junta Central de Contadores Públicos entre los años 2010 a $2017^{[6]}$

\section{Variables individuales}

\section{Género}

Se examina 559 sanciones y se encuentra que fueron sancionadas 231 mujeres y 328 hombres.

\begin{tabular}{|c|c|c|}
\hline Hombres & Mujeres & Total \\
\hline 328 & 231 & 559 \\
\hline
\end{tabular}

\begin{tabular}{|c|c|c|c|c|c|c|c|c|}
\hline 2010 & 2011 & 2012 & 2013 & 2014 & 2015 & 2016 & 2017 & Total \\
\hline 53 & 75 & 53 & 19 & 126 & 89 & 113 & 31 & 559 \\
\hline
\end{tabular}

2. Tipo de sanción

La sanción que más se impone es la suspensión, con un total de 510 veces entre 559 , representa el $91 \%$.

5 Algunos estudiantes firmaron los dibujos con su nombre y universidad, otros no lo hicieron. A todos se les informó que algunos de los dibujos serían seleccionados para incluirlos en un trabajo académico y estuvieron de acuerdo.

6 Un primer conjunto de sanciones impuestas entre los años 2010 a 2013 fueron analizadas y desarrolladas en conjunto con los estudiantes (ahora profesionales) Mónica Bedoya y Michael Aparicio (2013), del programa de Contaduría Pública de la Universidad Autónoma de Occidente en Cali, dicho análisis se presentó en el trabajo de grado Análisis descriptivo de las conductas que vulneran el código de ética del contador público según las sanciones emitidas por la Junta Central de Contadores Públicos entre los años 2010 a 2013. En esa oportunidad dirigí dicho trabajo de grado y diseñé los insumos metodológicos que se utilizaron en su desarrollo, en especial, la matriz y el desarrollo de sus campos. 


\begin{tabular}{|c|c|c|c|c|}
\hline Suspensión & Amonestación & Cancelación & Multa & Total \\
\hline 510 & 29 & 16 & 4 & 559 \\
\hline
\end{tabular}

\section{Tiempo de la sanción en meses}

El tiempo de la sanción que más se impone es de doce meses en 222 conductas sancionadas, este es el tiempo máximo de suspensión que permite la Ley 43 de 1990 en su artículo 25. Le sigue el tiempo de seis meses en 151 casos.

\begin{tabular}{|c|c|c|c|c|c|c|c|c|}
\hline $\mathrm{M}$ & 12 & 6 & 9 & 0 & 3 & 10 & 2 & 1 \\
\hline$\#$ & 222 & 151 & 70 & 35 & 51 & 2 & 3 & 6 \\
\hline
\end{tabular}

\section{Tipo de falta}

La falta que más se sanciona es "grave a título de culpa", en 281 conductas sancionadas, y le sigue "grave a título de dolo" en 236 casos. De acuerdo con el artículo 10: fe pública, de la Ley 43 de 1990, en su parágrafo se indica que al contador público se le juzgará como funcionario público para efectos de las sanciones penales. La graduación de los tipos de sanciones se estipula en el libro I, título V de la Ley 734 del 2002, del Código Disciplinario Único, artículos 44 a 47.

\begin{tabular}{|c|c|c|c|c|c|c|}
\hline $\begin{array}{c}\text { Grave a } \\
\text { título de } \\
\text { culpa }\end{array}$ & $\begin{array}{c}\text { Grave a } \\
\text { título de } \\
\text { dolo }\end{array}$ & $\begin{array}{c}\text { Leve a títu- } \\
\text { lo de culpa }\end{array}$ & $\begin{array}{c}\text { Leve a títu- } \\
\text { lo de dolo }\end{array}$ & $\begin{array}{c}\text { Título de } \\
\text { culpa }\end{array}$ & $\begin{array}{c}\text { Título de } \\
\text { dolo }\end{array}$ & Total faltas \\
\hline 281 & 236 & 29 & 2 & 6 & 2 & 556 \\
\hline
\end{tabular}

Los artículos 22 y 23 de la Ley 599 del 2000 (Código Penal) establecen la distinción entre la culpa y el dolo; a la primera, se le atribuye conocimiento de la consecuencia de la acción, pero inevitabilidad de esta se puede entender como un fallo por imprudencia; a la segunda, se la atribuye conocimiento de la consecuencia y realización de esta a pesar de poder evitarla. Se comete la falta con intención con dolo.

\section{Cargos sancionados}

El cargo más sancionado es el del contador en 437 conductas. Sin embargo, este resultado no es plenamente confiable, porque en algunas situaciones existe discrepancia entre la información que presenta la JCC en la conducta publicada, de este modo, en una misma conducta el encabezado de esta puede indicar un cargo y su descripción puede estar asociada a otro.

\begin{tabular}{|c|c|c|c|}
\hline Contador & Auditor & Revisor Fiscal & Total cargos \\
\hline 437 & 2 & 112 & 551 \\
\hline
\end{tabular}




\section{Conductas más sancionadas (mayor o igual a cinco casos)}

La conducta que más sancionó la JCC entre los años 2010 a 2017 fue "certificar información que no corresponde a la realidad material con el fin de solicitar saldos de impuestos a favor de sus clientes", en un total de 201 veces sobre 559 sanciones. Equivale al $36 \%$ del total de las sanciones y le sigue "retener injustificadamente información contable a uno de los usuarios de sus servicios", con un total de 44 repeticiones $(7 \%)$.

Se tomaron en cuenta las conductas sancionadas que se repitieron en un número igual o superior a cinco veces. Una vez organizada la información se obtuvieron 321 sanciones y se procedió a ordenarlas de forma descendente, obteniendo con ello las cinco conductas que con mayor frecuencia infringieron el Código de Ética Profesional del Contador Público en los últimos ocho años. Estas son las cinco conductas más sancionadas ${ }^{7}$ (ver tabla 1 ).

Tabla 1.

Conductas más sancionadas por la JCC entre el 2010 al 2017.

\begin{tabular}{|c|c|c|}
\hline \multicolumn{2}{|c|}{ Conductas más sancionadas (mayor o igual a cinco casos) } & Número \\
\hline 1 & $\begin{array}{c}\text { Certificar información que no corresponde a la realidad material con el fin de } \\
\text { solicitar saldos de impuestos a favor de sus clientes. }\end{array}$ & 201 \\
\hline 2 & $\begin{array}{c}\text { Retener injustificadamente información contable a uno de los usuarios de sus } \\
\text { servicios. }\end{array}$ & 44 \\
\hline 3 & $\begin{array}{c}\text { Certificar información contable que no corresponde de forma fidedigna con la } \\
\text { situación económica de la empresa. }\end{array}$ & 36 \\
\hline 4 & \begin{tabular}{c} 
Sustraer dinero (o capital económico) sin autorización y para beneficio personal \\
\hline
\end{tabular} & 25 \\
\hline
\end{tabular}

7 En un periodo de ocho años de conductas sancionadas por la JCC se puede identificar que la mayor ponderación de sanción recae sobre certificar información contable que no corresponde a la realidad económica del cliente, en 201 casos (36\% de 559), para ventajas fiscales a favor del cliente, y en 36 casos $(6,44 \%$ de 559$)$, para otro tipo de ventajas a favor del cliente. Ambas conductas suman un $42,44 \%$ de las conductas sancionadas que infringen el código de ética en principios como el de integridad, objetividad, independencia, fe pública, entre otros. Esto quiere decir que solo una parte de las conductas sancionadas se relacionan con comportamientos cercanos a la corrupción y a irregularidades normativas por parte de los profesionales de la contaduría pública. Al contador público se le sanciona por distintos motivos y no solamente por corrupción e irregularidades. Este resultado se opone a la generalización mediática de titulares como "504 contadores públicos han sido sancionados por casos de corrupción, revela informe" (Noticias Universitarias, 2018), "Más de 500 contadores públicos han sido sancionados por corrupción" (página web de RCN Radio), "Por irregularidades y corrupción, más de 500 contadores han sido sancionados en Colombia" (El Espectador, 2018), y "Por trampas, como la elusión, ya van 504 contadores sancionados" (El Tiempo, 2018). Los contadores sí fueron sancionados, pero no todos ellos por comportamientos relacionados con corrupción o irregularidades. 


\begin{tabular}{|c|c|c|}
\hline \multicolumn{2}{|c|}{ Conductas más sancionadas (mayor o igual a cinco casos) } & Número \\
\hline 5 & $\begin{array}{c}\text { Aceptar el cargo de revisor fiscal en una compañía en la cual existían situacio- } \\
\text { nes e incompatibilidades que afectaban su independencia y objetividad. Vulne- } \\
\text { rando el artículo 50 de la Ley 43 de 1990. }\end{array}$ & 15 \\
\hline & 321 \\
\hline
\end{tabular}

Fuente: elaboración propia.

\section{Artículos del código de ética más infringidos}

El principio ético de responsabilidad se infringe en un total de 453 veces en las conductas sancionadas, el de observancia de las disposiciones normativas le sigue en 394 veces; el principio "conducta ética", se infringe en 199 casos. Otros artículos del código de ética que se infringen con frecuencia son: el 70, evitar el fraude, en 199 veces y el 45, riesgos injustificados, 140 veces. Sobresale el artículo 70 del código de ética, porque se ve comprometido en la conducta que se sanciona con mayor frecuencia y que se relaciona con la defraudación fiscal. (Alterar información contable o emitir declaraciones tributarias no ajustadas a la realidad económica con el fin de obtener beneficios económicos para su cliente en detrimento del interés del Estado) (ver tabla 2).

Tabla 2.

Artículos del código de ética más infringidos entre los años 2010 a 2017.

\begin{tabular}{|c|l|c|}
\hline Artículo & \multicolumn{1}{|c|}{ Nombre } & Número \\
\hline 37.4 & Responsabilidad & 453 \\
\hline 37.6 & Observancia de las normas & 394 \\
\hline 70 & Evitar fraude & 199 \\
\hline 37.10 & Conducta ética & 122 \\
\hline 45 & Riesgos injustificados & 140 \\
\hline 37.1 & Integridad & 94 \\
\hline 37.2 & Objetividad & 41 \\
\hline 37.3 & Independencia & 38 \\
\hline 50 & Independencia que depende factores externos & 27 \\
\hline 69 & Certificación o dictamen ceñida a la verdad & 18 \\
\hline 51 & Independencia que depende del contador y su cargo & 12 \\
\hline 37.7 & Competencia y actualización profesional & 8 \\
\hline 48 & No ser contador si antes fue auditor o revisor & 6 \\
\hline 57 & Conceptuar sobre el trabajo de otro contador sin soportes & 6 \\
\hline 42 & Evitar cargos sin libre y correcto ejercicio profesional & 4 \\
\hline 37.9 & Respeto entre colegas & 3 \\
\hline 43 & Sin idoneidad & 3 \\
\hline 37.5 & Confidencialidad & 1 \\
\hline 37.8 & Difusión y colaboración & 0 \\
\hline
\end{tabular}

Fuente: elaboración propia. 


\section{Variables relacionadas}

Se pretende relacionar una conducta sancionada con el tipo de sanción y de falta que la junta dispone. Con ello reconocer si los mismos comportamientos se juzgan igual cada vez o si existen variaciones. También se relaciona la conducta sancionada y su consecuencia en el código de ética, para identificar si los mismos comportamientos infringen igual al código de ética según el fallo de la junta o si existen variaciones. Para lo anterior, solo se usaron las conductas sancionadas iguales o superiores a cinco repeticiones. Los resultados se presentan de forma separada por cada tipo de relación pretendida (ver tablas 3 y 4).

Tabla 3.

Relación entre conducta, sanción y tipo de falta.

\begin{tabular}{|c|c|c|c|c|c|c|c|c|c|}
\hline \# & Conducta sancionada & $\mathrm{R}$ & 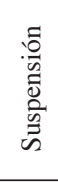 & 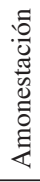 & 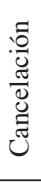 & $\stackrel{\frac{\pi}{\leftrightarrows}}{\stackrel{\Xi}{\Xi}}$ & 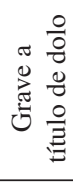 & 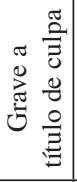 & 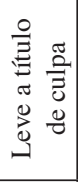 \\
\hline 1 & $\begin{array}{l}\text { Certificar información que no corresponde a la } \\
\text { realidad material con el fin de solicitar saldos de } \\
\text { impuestos a favor de sus clientes. }\end{array}$ & 201 & 196 & 4 & 1 & 0 & 159 & 38 & 4 \\
\hline 2 & $\begin{array}{l}\text { Retener injustificadamente información contable } \\
\text { a uno de los usuarios de sus servicios. }\end{array}$ & 44 & 39 & 4 & 0 & 1 & 2 & 36 & 4 \\
\hline 3 & $\begin{array}{l}\text { Certificar información contable que no co- } \\
\text { rresponde de forma fidedigna con la situación } \\
\text { económica de la empresa. }\end{array}$ & 36 & 35 & 1 & 0 & 0 & 27 & 8 & 1 \\
\hline 4 & $\begin{array}{l}\text { Sustraer dinero (o capital económico) sin auto- } \\
\text { rización y para beneficio personal }\end{array}$ & 25 & 20 & 1 & 4 & 0 & 19 & 5 & 1 \\
\hline 5 & $\begin{array}{l}\text { Aceptar el cargo de revisor fiscal en una com- } \\
\text { pañía en la cual existían situaciones e incom- } \\
\text { patibilidades que afectaban su independencia } \\
\text { y objetividad. Vulnerando el artículo } 50 \text { de la } \\
\text { Ley } 43 \text { de } 1990 \text {. }\end{array}$ & 15 & 14 & 1 & 0 & 0 & 2 & 12 & 1 \\
\hline
\end{tabular}

Fuente: elaboración propia. 


\begin{tabular}{|c|c|c|c|c|c|c|c|}
\hline & 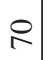 & $\stackrel{\bullet}{n}$ & 0 & \pm & 0 & - & $\Xi$ \\
\hline & gิ & \pm & 0 & 0 & 0 & 0 & \pm \\
\hline & in & 0 & 0 & 0 & 0 & $\simeq$ & $\simeq$ \\
\hline & $\underset{+}{+}$ & 0 & 0 & - & 0 & 0 & - \\
\hline & $\mathscr{f}$ & I & $\hat{n}$ & 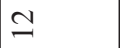 & \pm & 0 & $\infty$ \\
\hline & 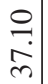 & in & $\infty$ & $\infty$ & તి & $m$ & $\infty$ \\
\hline & n. & - & 0 & 0 & - & 0 & N \\
\hline : & \begin{tabular}{|l|}
0 \\
$\infty$ \\
$m$
\end{tabular} & ป & $m$ & $\stackrel{a}{a}$ & 근 & in & ठ্ \\
\hline $\begin{array}{l}0 \\
0\end{array}$ & $\begin{array}{l}+ \\
\text { m. }\end{array}$ & $\mathscr{\infty}$ & q & $\bar{m}$ & $\infty$ & 0 & $\underset{⿱ 亠}{\infty}$ \\
\hline '] & $m$ & $N$ & 0 & 0 & 0 & $ㅇ$ & $\simeq$ \\
\hline $\overrightarrow{0}$ & ñ & - & 0 & 0 & 0 & $\infty$ & $a$ \\
\hline 式 & $\frac{1}{m}$ & फे & 0 & 0 & 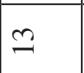 & - & 8 \\
\hline$\dot{0}$ & $\hat{n}$ & & $\infty$ & $=$ & $a$ & $\sim$ & in \\
\hline 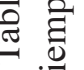 & $\Xi$ & $\sim$ & $\stackrel{\circ}{\circ}$ & 0 & $m$ & $n$ & \\
\hline శే & छี & $\Xi$ & 9 & $\stackrel{0}{-}$ & - & $r$ & \\
\hline 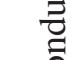 & $\Xi$ & 0 & 0 & - & $\sim$ & $m$ & \\
\hline$\stackrel{\circlearrowright}{\Xi}$ & $\underset{\Xi}{\Xi}$ & $\stackrel{n}{n}$ & - & $\because$ & 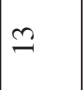 & 0 & \\
\hline :0ิ & $\simeq$ & $\overrightarrow{\text { ¿ }}$ & $\forall$ & r & $\approx$ & $\because$ & $\vec{\sim}$ \\
\hline$\frac{\widetilde{\Xi}}{\vec{Q}}$ & 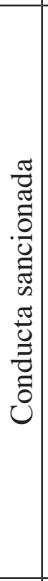 & 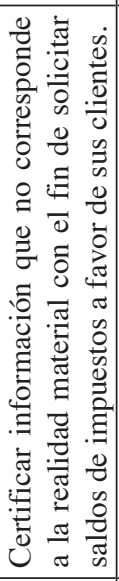 & 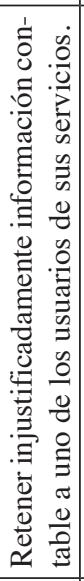 & 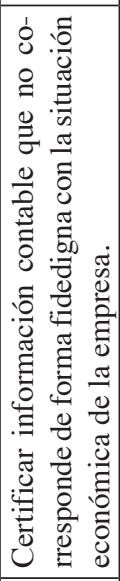 & 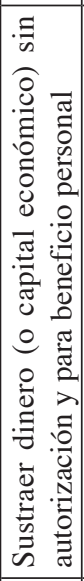 & 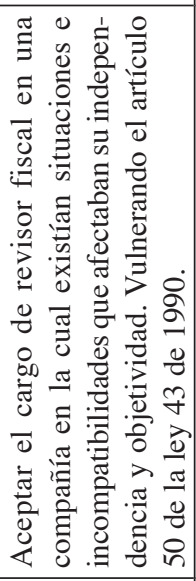 & \\
\hline & * & - & $N$ & $m$ & $\nabla$ & in & \\
\hline
\end{tabular}


Con la información así tabulada se procedió a elaborar dos gráficos (1 y 2) de arañas (así su nombre por la forma), con el fin de comparar las cinco conductas y la frecuencia de sus atributos (sanción, falta, tiempo, código de ética).

\section{Gráfico 1. \\ Conducta-sanción-falta-tiempo}

\footnotetext{
Certificar información que no corresponde a la realidad material con el fin de solicitar saldos de impuestos a favor de sus clientes.

Retener injustificadamente información contable a uno de los usuarios de sus servicios.

- Certificar información contable que no corresponde de forma fidedigna con la situación económica de la empresa.

Sustraer dinero (o capital económico) sin autorización y para beneficio personal

- Aceptar el cargo de revisor fiscal en una compañía en la cual existian situaciones e incompatiblidades que afectaban su independencia y objetividad. Vulnerando el artículo 50 de la Ley 43 de 1990.
}

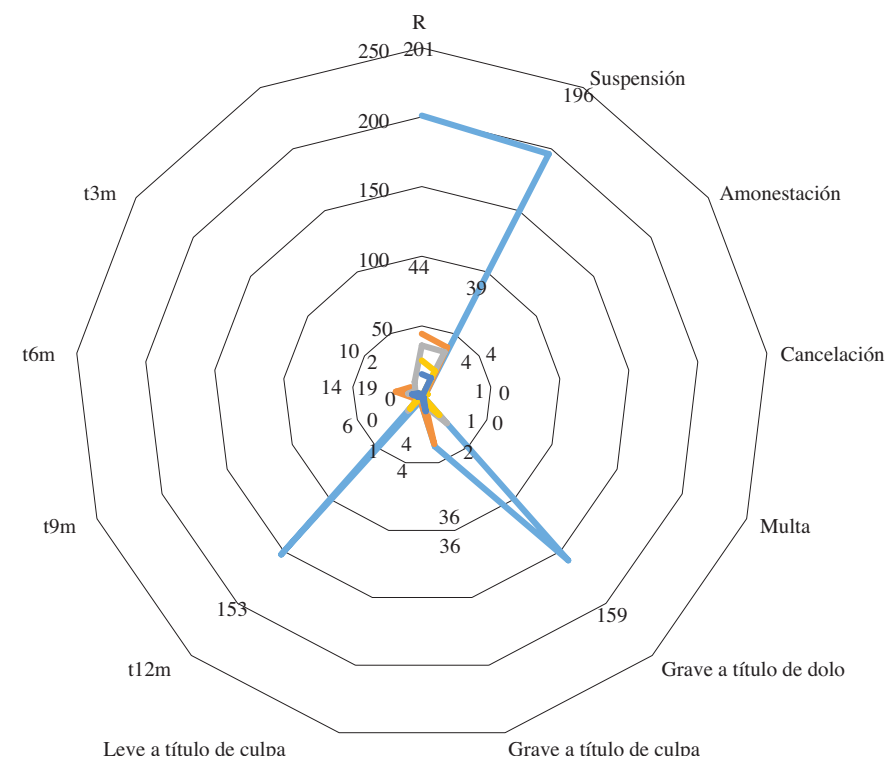

Fuente: elaboración propia.

Gráfico 1: la conducta más sancionada "certificar información que no corresponde a la realidad material con el fin de solicitar saldos de impuestos a favor de sus clientes" suele recibir el tipo de sanción: "suspensión", el tipo de falta "grave a título de dolo" y el tiempo de doce meses para la suspensión. El contador público que comete esta falta está en la capacidad de prever las consecuencias de certificar información tributaria que no corresponde a la realidad económica con el propósito de favorecer a sus clientes, con ello participa de evasión fiscal y de algún modo sustrae dineros que por ley se le deben entregar al Estado. En su orden le sigue la conducta "retener injustificadamente información contable a uno de los usuarios de sus servicios", esta suele recibir la sanción de "suspensión", el tipo de falta "grave a título de culpa" y un tiempo de sanción de seis meses. 


\section{Gráfico 2.}

\section{Conducta-sanción-artículos}
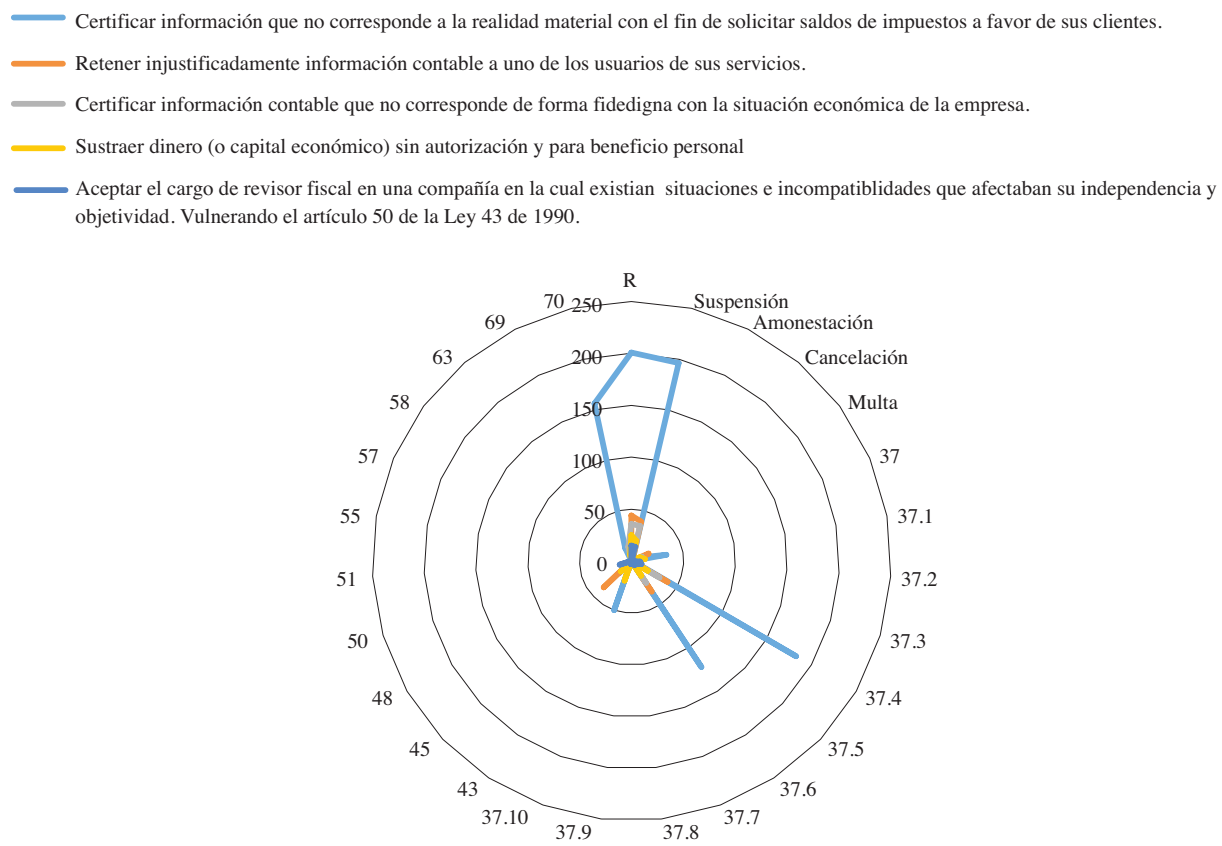

Fuente: elaboración propia.

Gráfico 2: la conducta más sancionada "certificar información que no corresponde a la realidad material con el fin de solicitar saldos de impuestos a favor de sus clientes" suele infringir los principios de responsabilidad, observancia de las disposiciones normativas y conducta ética; en su orden le sigue la conducta "retener injustificadamente información contable a uno de los usuarios de sus servicios", esta suele infringir los principios de responsabilidad y observancia de las disposiciones normativas, así como el artículo 45 , exponer a riesgos injustificados.

Otros resultados relacionados con la caracterización del mal contable en Colombia (2010-2017)

\section{La misma conducta se juzga de forma diferente en cuanto a la sanción y el tipo de falta}

Se observa que un mismo comportamiento recibe diferente tratamiento. Se puede decir que en el caso de la conducta que más infringe el código de ética existe un criterio o tendencia a que la sanción sea de suspensión, no sucede igual en la determinación de la culpabilidad en algunos casos se considera de dolo y en otros de culpa. Sin embargo, una vez se altera la representación contable para fallar a favor del cliente y en contra del Estado, sin importar la cuantía de la alteración, 
el contador falta a la verdad, a la fe pública y sus principios éticos. Aquí se puede ver cómo esta conducta presenta variaciones en su tratamiento.

Tabla 5.

Diferente sanción y falta para una misma conducta

\begin{tabular}{|c|c|c|c|c|c|c|c|c|c|}
\hline \# & Conducta sancionada & $\mathrm{R}$ & 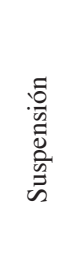 & 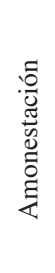 & 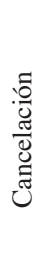 & $\frac{\pi}{3}$ & $\begin{array}{l}0 \\
\stackrel{0}{0} \\
0 \\
0 \\
0 \\
0 \\
\Xi \\
0 \\
0 \\
0 \\
0 \\
0\end{array}$ & 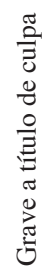 & 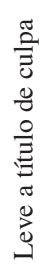 \\
\hline 1 & $\begin{array}{l}\text { Certificar información que no corresponde a la } \\
\text { realidad material con el fin de solicitar saldos de } \\
\text { impuestos a favor de sus clientes. }\end{array}$ & 201 & 196 & 4 & 1 & 0 & 159 & 38 & 4 \\
\hline
\end{tabular}

Fuente: elaboración propia.

\section{La misma conducta infringe de forma diferente el código de ética profesional}

Se observa que la conducta que más infringe el código de ética profesional suele infringir los principios de responsabilidad, de observancia de las disposiciones normativas y el artículo 70, que se relaciona con evitar el fraude. Sin embargo, se observa que el mismo comportamiento afecta dichos artículos de manera no uniforme. Para el total de 201 conductas sancionadas, en 183 casos afectó el principio de responsabilidad y en 122, el de observancia, y en 156, el de evitar el fraude. No se está sugiriendo que deba existir un patrón o modelo por conducta, porque se juzgan acciones humanas, pero es importante conservar criterios mínimos para juzgar el comportamiento profesional. Ante la situación de que un contador participa en fraude fiscal, en algunos casos se le juzga no responsable y en otros no, en unos casos se le juzga por no observar las normas, mientras que en otros, a pesar de no observarlas, no se señala dicho artículo. Es posible que la JCC no siga un esquema de sanciones según una tipificación de conductas y ello conlleve a estas variaciones. 
Tabla 6.

Diferentes artículos del código de ética infringidos por una mima conducta.

El comportamiento que vulnera la ética profesional, desplegado por el investigado se puede calificar como grave dadas las circunstancias en que cometió la falta, que recae sobre certificar con su firma información contraria a la realidad al momento de presentar las declaraciones del impuesto a la renta de los años 2011 y 2012, presentada los días 18 de abril del 2012 y 16 de abril del 2013, y fueron corregidas el día 10 de octubre del 2013, teniendo en cuenta que se incluyeron ingresos y costos improcedentes; la trascendencia social de los hechos endilgados y la implicación negativa frente a la imagen de la profesión que desarrolla; pues desconoció las normas de la ética y las del ejercicio de su profesión y, se atribuye a título de dolo, en virtud del conocimiento de la actividad contable que presupone un actuar conforme a las normas vigentes; de igual manera, pues desatendió su deber profesional, por cuanto el profesional en la ciencia contable conoce las obligaciones en la prestación de los servicios de contaduría y, aun así, con su firma certificó hechos económicos contenidos en las declaraciones de renta de los años gravable 2011 y 2012 , que generaron una carga impositiva al contribuyente relacionada con el pago de las sanciones por valores de \$39010000 y \$60681000, vulneró las disposiciones normativas contenidas en los artículos 10,37.4, 37.6, 37.10 y 70 de la Ley 43 de 1990.

\begin{tabular}{|l|c|c|c|c|c|c|c|c|c|c|c|c|c|c|c|}
\hline$\#$ & Conducta sancionada & $\mathrm{R}$ & $\mathrm{t} 12 \mathrm{~m}$ & $\mathrm{t} 6 \mathrm{~m}$ & 37 & 37.1 & 37.2 & 37.3 & 37.4 & 37.6 & 37.7 & 37.10 & 45 & 69 & 70 \\
\hline 1 & $\begin{array}{l}\text { Certificar información } \\
\text { que no corresponde a } \\
\text { la realidad material con } \\
\text { el fin de solicitar saldos } \\
\text { de impuestos a favor de } \\
\text { sus clientes. }\end{array}$ & 201 & 153 & 14 & 10 & 34 & 1 & 2 & 183 & 122 & 1 & 50 & 17 & 14 & 156 \\
\end{tabular}

Fuente: elaboración propia.

- La conducta sancionada infringe principios éticos importantes que no son sancionados por la Junta

Siguiendo el mismo caso de la conducta más sancionada, un hecho en el cual el contador público certifica información tributaria que no corresponde a la realidad económica del cliente, con el fin favorecerlo y en detrimento del Estado, afecta directamente principios éticos como el de integridad, objetividad e independencia, sin embargo, la JCC no los incluye en sus sanciones. Se puede observar que la conducta más sancionada, que suma un total de 201 casos, solo afecta el principio de integridad 34 veces, el de objetividad, una vez, y el de independencia, 2 veces.

- La JCC atribuye que el dolo del contador público es de su exclusiva responsabilidad y discrecionalidad

En relación con la conducta más sancionada, que se viene describiendo, la JCC suele mencionar que la DIAN realizó inspección de la falta y en consecuencia sancionó a 
la entidad económica con las amonestaciones tributarias que corresponden según la situación juzgada, en esa circunstancia, la JCC da a entender que el contador público es culpable de la sanción que recibe la empresa, por el hecho de estar en la capacidad de prever las consecuencias de su comportamiento. Este es un ejemplo de tal afirmación:

La JCC sugiere en algunos de sus fallos que el contador público de forma discrecional provoca las sanciones que le impone la DIAN a la empresa, una vez se establece que la información tributaria presentada no corresponde a la realidad económica de la entidad. Sin embargo, sostener tal cosa supone una mirada muy simplificada de las relaciones de poder que subyacen en la elaboración de información contable con carácter tributario y desconoce el poder de influencia de los dueños de las empresas, incluso de la gerencia, sobre los resultados esperados en un menor impacto financiero derivado de las cargas impositivas.

- Esquemas normativos para el aprendizaje del código de ética profesional

Una vez caracterizado el "mal contable" en Colombia, se procede a presentar un mecanismo de simplificación normativa que permite mejorar el proceso de aprendizaje del código de ética profesional. Según el análisis realizado se encuentra que artículos como el de la fe pública, responsabilidad, observancia de las normas, riesgos injustificados y el artículo 70, que sugiere que el contador debe obrar según la verdad, son los que con mayor frecuencia se infringen. A continuación, se presentan cinco ejemplos de lo que serían dichos esquemas. En el anexo se puede detallar la forma de construirlos.

8 Se procede del siguiente modo: el cajón superior contiene la norma según su fuente jurídica; el cajón izquierdo incluye los símbolos o convenciones que se usarán en el esquema normativo; el cajón derecho presenta la relación de dichos símbolos o esquema de la norma, se lee de izquierda a derecha y recupera el contenido de la norma mediante la imagen y su configuración simbólica. 
Imagen 2.

Esquema normativo de la fe pública. Art. 10. De la fe pública ${ }^{8}$

\begin{abstract}
La atestación o firma de un contador público en los actos propios de su profesión hará presumir, salvo prueba en contrario, que el acto respectivo se ajusta a los requisitos legales, lo mismo que a los estatutarios en casos de personas jurídicas. Tratándose de balances, se presumirá además que los saldos se han tomado fielmente de los libros, que estos se ajustan a las normas legales y que las cifras registradas en ellos reflejan en forma fidedigna la correspondiente situación financiera en la fecha del balance.
\end{abstract}

Fcp: firma de un contador público

$$
\text { :en los }
$$

App: actos propios de su profesión

Pr: presumir

$\sqrt{ }$ cc: cumple con

RI: requisitos legales

$\mathrm{Re}$ : requisitos estatutarios

Ba: balances

Sfl: saldos fieles de los libros

$\mathrm{NI}$ : normas legales

Rf: reflejo fidedigno

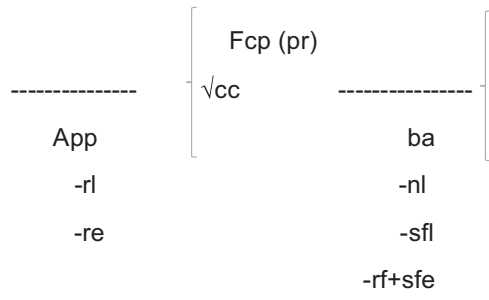

Fuente: elaboración propia.

Imagen 3.

Esquema normativo del principio ético: responsabilidad Art. 37.4. Responsabilidad

\begin{abstract}
Sin perjuicio de reconocer que la responsabilidad, como principio de la ética profesional, se encuentra implícitamente comprendida en todas y cada una de las normas de ética y reglas de conducta del contador público, es conveniente y justificada su mención expresa como principio para todos los niveles de la actividad contable. En efecto, de ella fluye la necesidad de la sanción, cuyo reconocimiento en normas de ética, promueve la confianza de los usuarios de los servicios del contador público, compromete indiscutiblemente la capacidad calificada, requerida por el bien común de la profesión.
\end{abstract}

Re: responsabilidad

Pri: principio

$\Sigma$ : todos

Nac: niveles de actividad contable

$$
\text { : fluye }
$$

Ns: necesidad de sanción

Pr: promueve

$\mathrm{Cu}$ : confianza de los usuarios

Cc: capacidadcalificada

Co: compromete

Rbcp: requerida para el bien común de la Profesión

FI: fluye
Art. 37.4. Responsabilidad

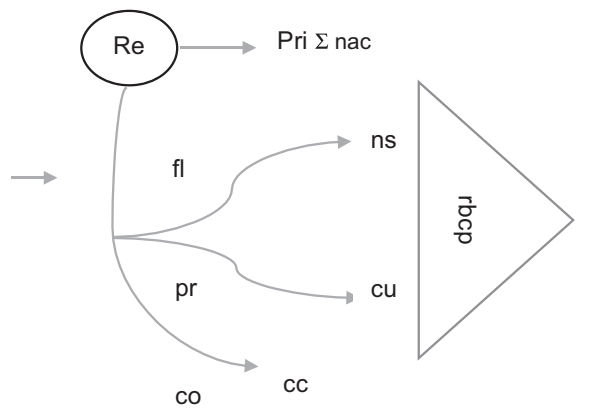

Fuente: elaboración propia. 


\section{Imagen 4.}

Esquema normativo del principio ético: observancia de las disposiciones normativas. Art. 37.6. Observancia de las disposiciones normativas

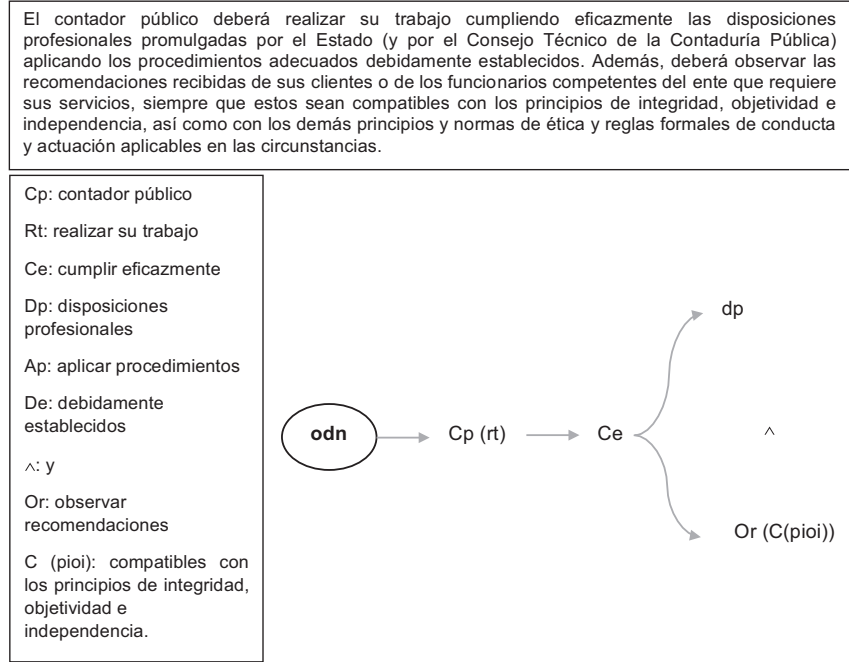

Fuente: elaboración propia.

\section{Imagen 5.}

Esquema normativo del artículo 70. Para garantizar la confianza pública Art. 70. Para garantizar la confianza pública

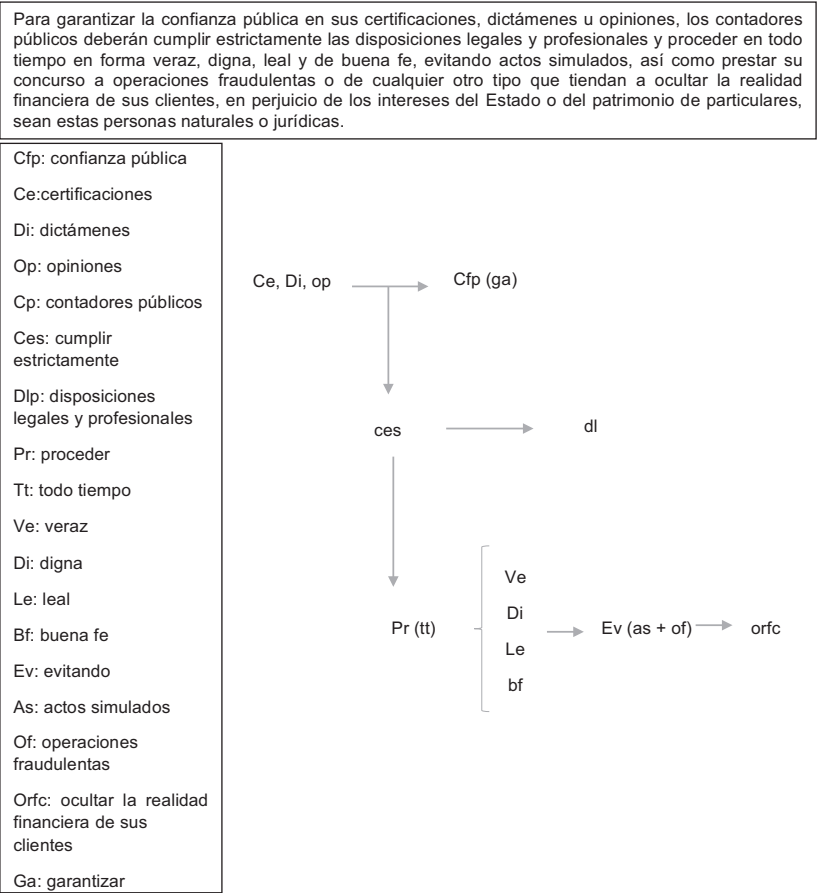

Fuente: elaboración propia. 
Imagen 6.

Esquema normativo del Artículo 45. Riesgos injustificados

Art. 45. Riesgos injustificados

\begin{tabular}{|l|}
\hline El contador público no expondrá al usuario de sus servicios a riesgos injustificados. \\
\hline \hline Cp: contador público \\
$\neg:$ no \\
$\begin{array}{ll}\text { Ex: exponer } \\
\text { Us: usuario }\end{array}$ \\
$\begin{array}{l}\text { Ri: } \\
\text { injustificados resgos }\end{array}$ \\
\hline
\end{tabular}

Fuente: elaboración propia.

\section{Imágenes del mal contable en Colombia entre los años 2010 a 2017}

Las cinco conductas más sancionadas por la Junta Central de Contadores Públicos se pueden representar mediante imágenes. Certificar información que no corresponde a la realidad económica del cliente, retener los libros de contabilidad y sustraer dinero para beneficio personal (ver imagen 7).

Imagen 7.

Alterando la realidad ${ }^{9}$

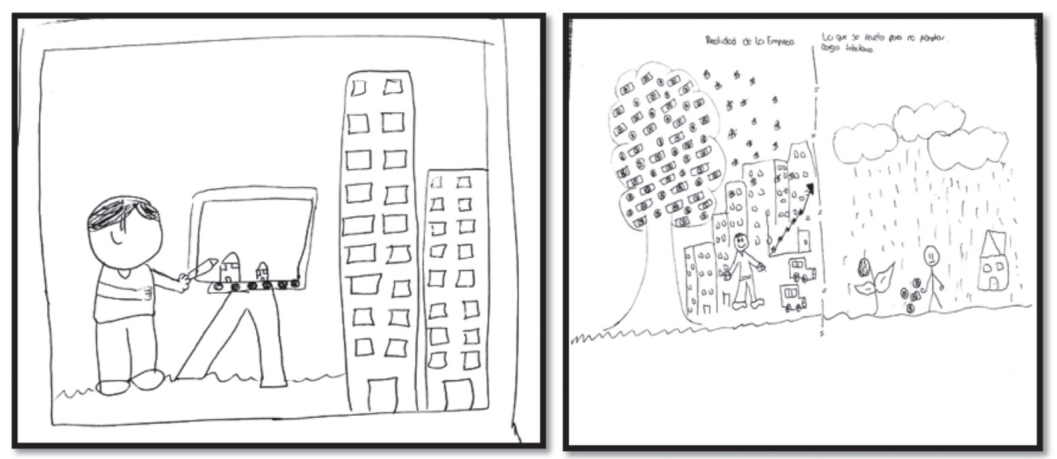

Fuente: dibujos del "mal contable" realizados por algunos estudiantes que asistieron a la quinta sesión de la cátedra itinerante de ética profesional (2018-1).

9 Imágenes del mal contable en Colombia que se podrían asociar a conductas como: certificar dos o más estados financieros que presentan diferencias entre sí a pesar de ser de un mismo periodo y compañía; certificar información contable que no corresponde de forma fidedigna con la situación económica de la empresa; certificar información que no corresponde a la realidad material con el fin de presentar informes favorables ante entidades estatales; certificar información que no corresponde a la realidad material con el fin de solicitar saldos de impuestos a favor de sus clientes; certificar que una entidad consignó en sus cuentas bancarias el total del capital pagado cuando en realidad no se consignó dicha suma; otras. 


\section{Imagen 8.}

¿La DIAN o mi cliente? ${ }^{10}$
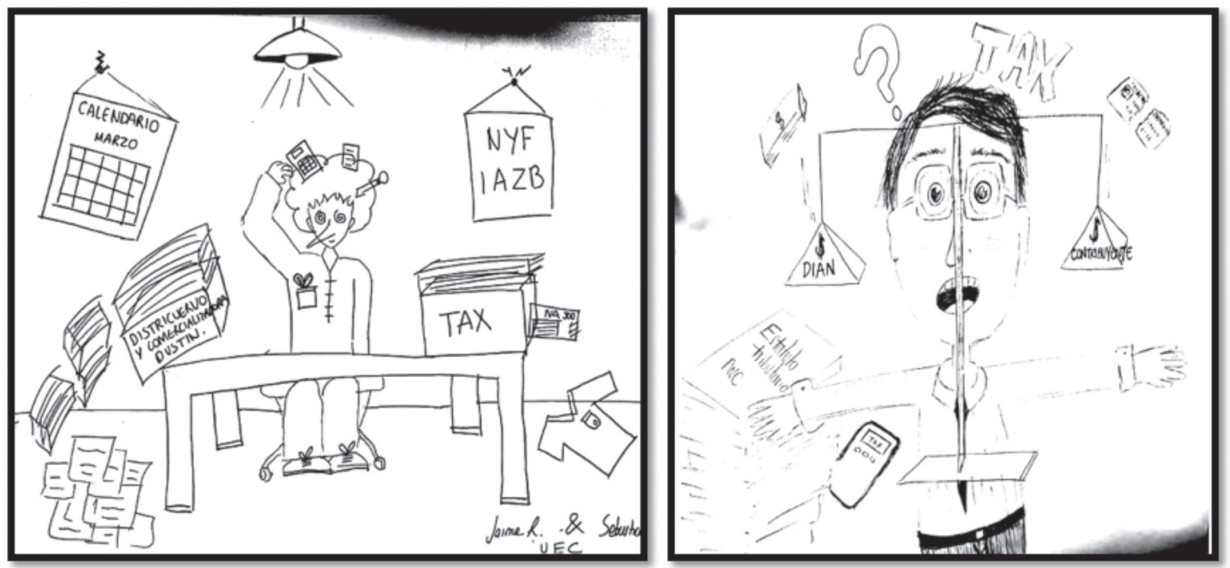

Fuente: dibujos del "mal contable" realizados por algunos estudiantes que asistieron a la quinta sesión de la cátedra itinerante de Ética Profesional (2018-1).

Imagen 9.

¿Y la responsabilidad? ${ }^{11}$

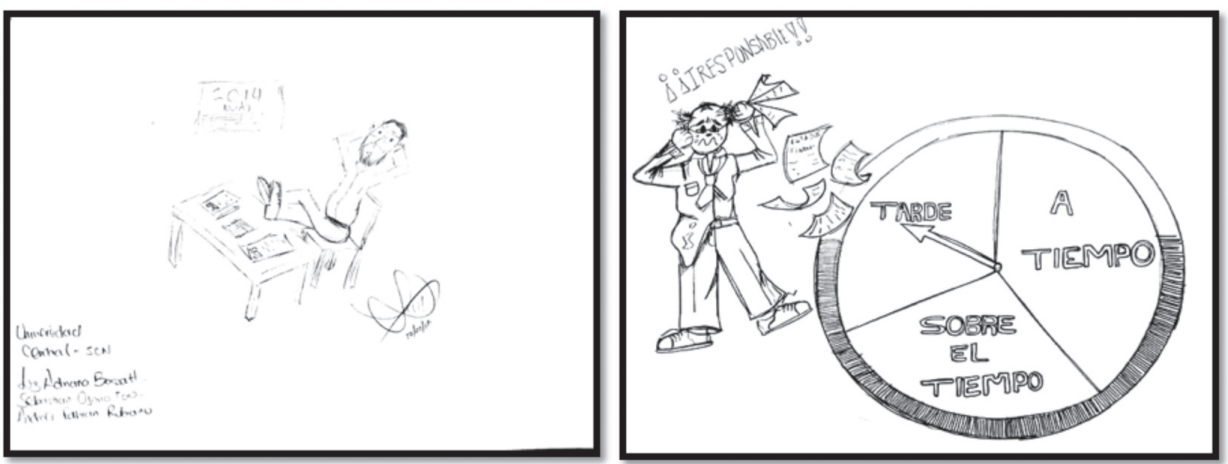

Fuente: dibujos del "mal contable" realizados por algunos estudiantes que asistieron a la quinta sesión de la cátedra itinerante de Ética Profesional (2018-1).

10 Imágenes del mal contable que servirían para ilustrar cómo se infringen los principios éticos de integridad, objetividad e independencia. Dibujos realizados por estudiantes de la Universidad Externando de Colombia.

11 Imágenes que se pueden asociar a comportamientos como: incumplir con el procesamiento oportuno de la información contable, incumplir con la entrega oportuna de la información contable y financiera en los periodos requeridos por la entidad, incumplir con la presentación y pago oportuno de las declaraciones tributarias, incumplir con la presentación del dictamen de los estados financieros ante la asamblea, otras. La imagen de la izquierda fue aportada por un estudiante del programa de Contaduría Pública de la Universidad Central. 
Imagen 10.

¿Y quién se llevó los libros? ${ }^{12}$

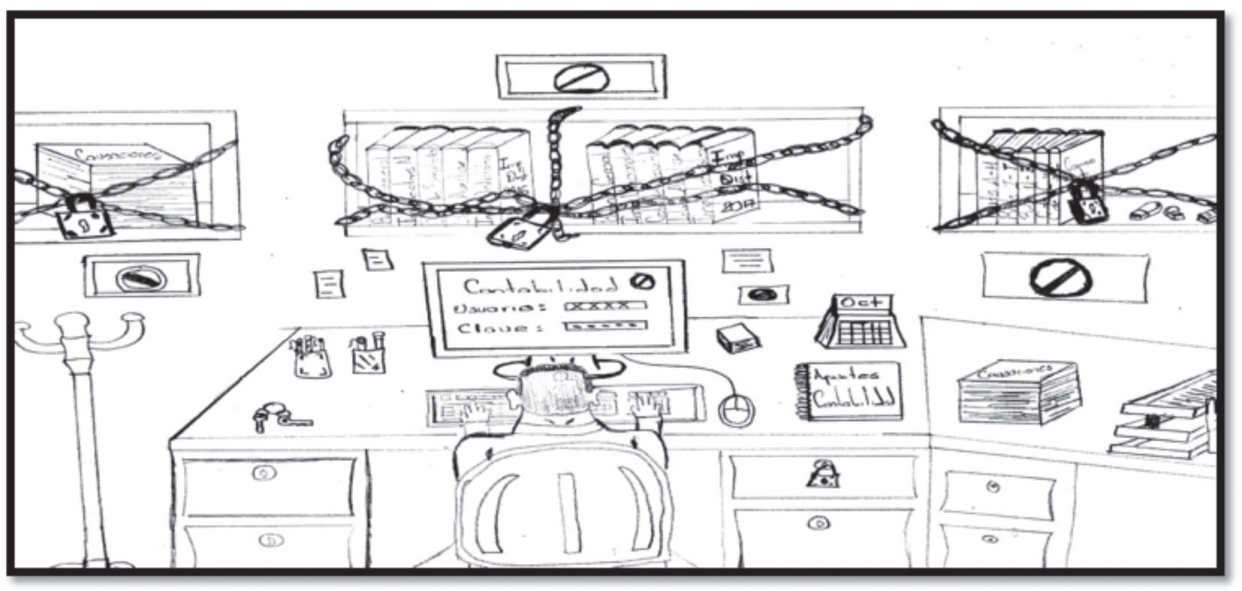

Fuente: elaborada por Wilson Buitrago, estudiante del programa de Contaduría Pública de la Fundación Universitaria Los Libertadores.

Imagen 11.

¿Y dónde está el dinero? ${ }^{13}$

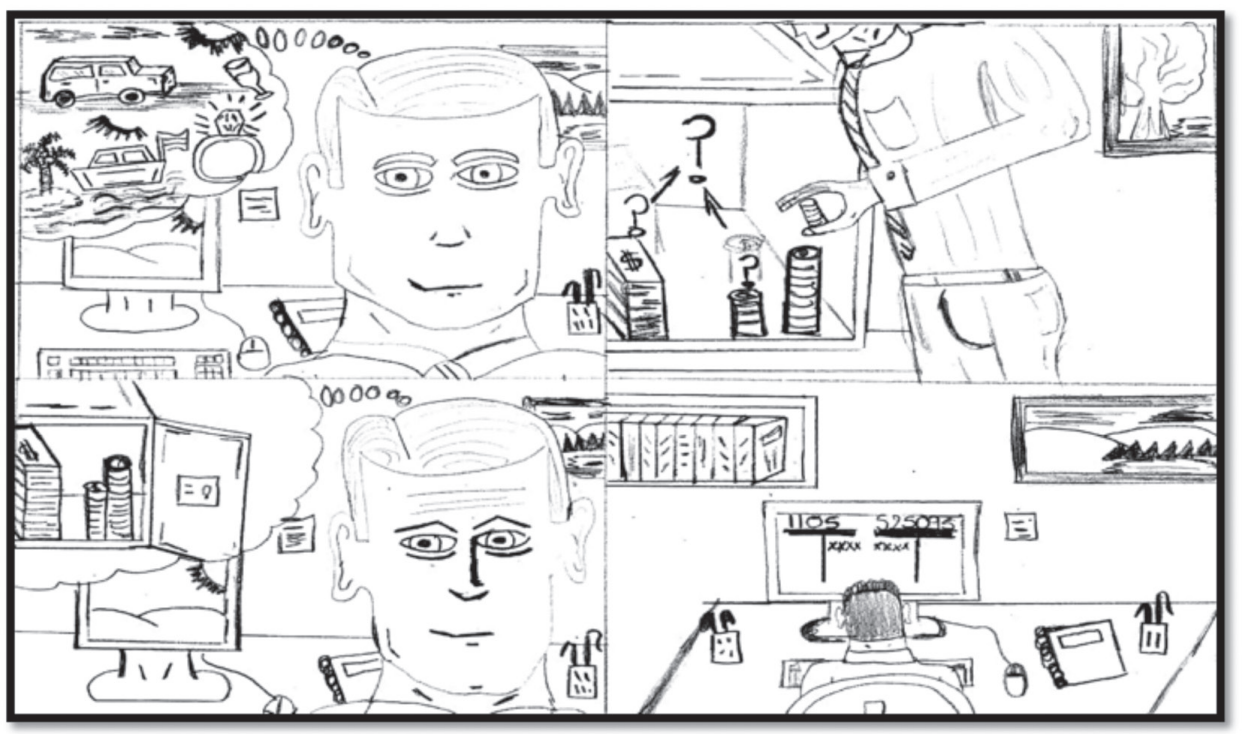

Fuente: elaborada por Wilson Buitrago, estudiante del programa de Contaduría Pública de la Fundación Universitaria Los Libertadores.

12 Se asocia a la segunda conducta que más infringe el código de ética: Retener injustificadamente información contable a uno de los usuarios de sus servicios.

13 Se asocia a la cuarta conducta que más infringe el código de ética: sustraer dinero (o capital económico) sin autorización y para beneficio personal. 


\section{Insumo didáctico para el reconocimiento de las conductas sancionadas}

Se presenta un instrumento de reconocimiento y caracterización de las conductas sancionadas ${ }^{14}$. El insumo didáctico tendría la siguiente forma antes de su diligenciamiento (tabla 7).

Tabla 7.

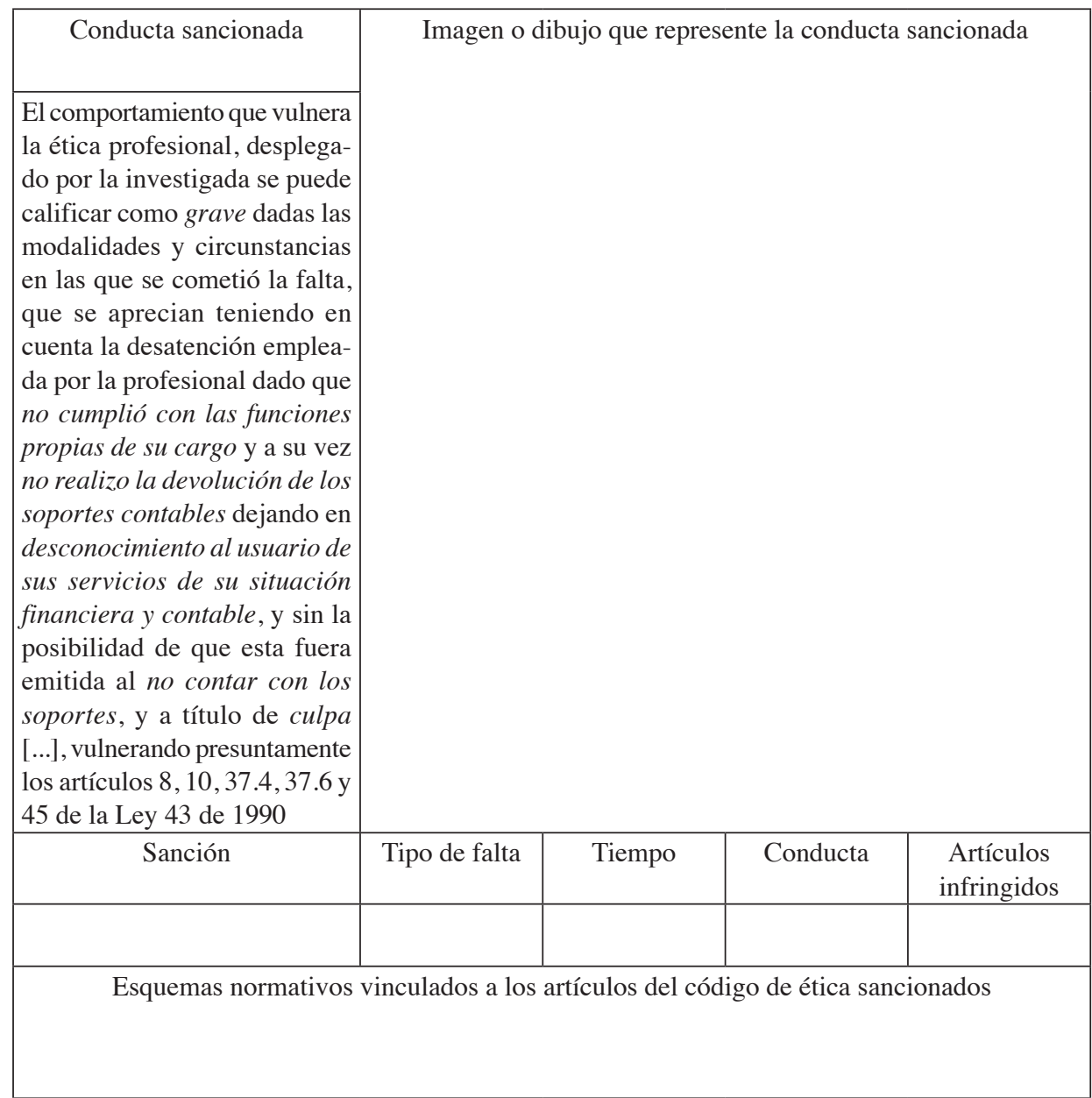

El insumo didáctico una vez diligenciado se vería del siguiente modo:

14 En este se presenta la sanción emitida por la JCC, la discriminación de las variables más significativas, los esquemas normativos vinculados a los artículos del código de ética que se sancionan y una imagen o dibujo que exprese el mal contable en dicha sanción. 
Tabla 8 .

Insumo didáctico para la descripción de las conductas sancionadas y su consecuencia en la ética profesional

\begin{tabular}{|c|c|c|c|c|}
\hline Conducta sancionada & & & & \\
\hline $\begin{array}{l}\text { El comportamiento que } \\
\text { vulnera la ética profe- } \\
\text { sional, desplegado por } \\
\text { la investigada se puede } \\
\text { calificar como GRAVE } \\
\text { dadas las modalidades } \\
\text { y circunstancias en las } \\
\text { que se cometió la falta, } \\
\text { que se aprecian teniendo } \\
\text { en cuenta la desatención } \\
\text { empleada por la profesio- } \\
\text { nal dado que no cumplió } \\
\text { con las funciones propias } \\
\text { de su cargo y a su vez no } \\
\text { realizo la devolución de } \\
\text { los soportes contables de- } \\
\text { jando en desconocimiento } \\
\text { al usuario de sus servicios } \\
\text { de su situación financiera } \\
\text { y contable, y sin la posi- } \\
\text { bilidad de que esta fuera } \\
\text { emitida al no contar con } \\
\text { los soportes, y a título de } \\
\text { CULPA [...], vulnerando } \\
\text { presuntamente los artícu- } \\
\text { los } 8,10,37.4,37.6 \text { y } 45 \\
\text { de la Ley } 43 \text { de } 1990\end{array}$ & & & & \\
\hline Sanción & Tipo de falta & Tiempo & Conducta & $\begin{array}{l}\text { Artículos } \\
\text { infringidos }\end{array}$ \\
\hline Suspensión & $\begin{array}{c}\text { Grave a título } \\
\text { de culpa }\end{array}$ & 9 & $\begin{array}{c}\text { Retener injus- } \\
\text { tificadamente } \\
\text { información } \\
\text { contable a uno } \\
\text { de los usuarios } \\
\text { de sus servicios }\end{array}$ & 37,$4 ; 37,6 ; 45$ \\
\hline
\end{tabular}
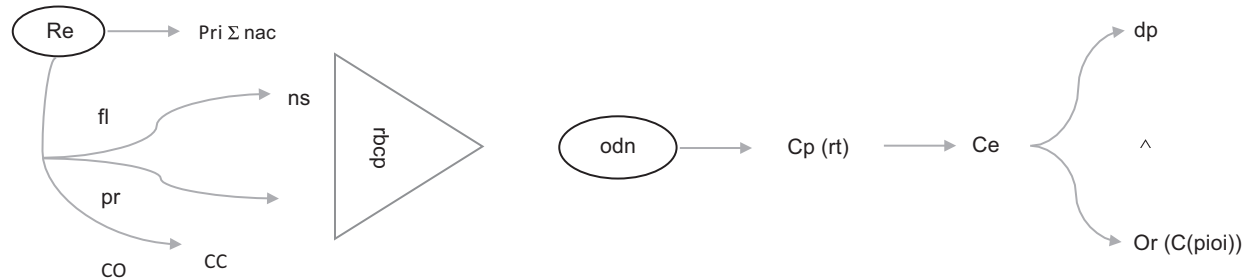


\section{CONCLUSIONES}

Las cinco conductas más sancionadas por la Junta Central de Contadores Públicos entre los años 2010 a 2017 son, en su orden: 1) Certificar información que no corresponde a la realidad material con el fin de solicitar saldos de impuestos a favor de sus clientes, 2) Retener injustificadamente información contable a uno de los usuarios de sus servicios, 3) Certificar información contable que no corresponde de forma fidedigna con la situación económica de la empresa, 4) Sustraer dinero (o capital económico) sin autorización y para beneficio personal, y, 5) Aceptar el cargo de revisor fiscal en una compañía en la cual existían situaciones e incompatibilidades que afectaban su independencia y objetividad. Vulnerando el artículo 50 de la Ley 43 de 1990.

Las sanciones y tipos de faltas que más se imponen son: suspensión (510-91 \%) y grave a título de culpa (281-50\%) y grave a título de dolo (236-42\%). Los artículos del código de ética que más se infringen son: 37,4 responsabilidad (453), 37,6 observancia de las disposiciones normativas (394), art. 70 (199), art. 45 (140) y el 37,10 conducta ética (199).

A la conducta más sancionada "certificar información que no corresponde a la realidad material con el fin de solicitar saldos de impuestos a favor de sus clientes", se le asocia con frecuencia la suspensión, la falta grave a título de dolo y un tiempo de doce meses para la sanción y suele infringir los principios de responsabilidad, observancia de las disposiciones normativas y conducta ética.

A la segunda conducta más representativa "retener injustificadamente información contable a uno de los usuarios de sus servicios", se le asocia la "suspensión", la falta "grave a título de culpa" y un tiempo de sanción de seis meses. Esta suele infringir los principios de responsabilidad y observancia de las disposiciones normativas, y el artículo 45 , exponer a riesgos injustificados.

Es posible que los fallos en el comportamiento ético del contador público tengan como una de sus causas el proceso formativo en ética profesional, se considera que desde dicho espacio es posible mejorar la forma como los profesionales en formación aprenden la conducta ética esperada. Se propone el uso de esquemas o diagramas normativos que permitan simplificar la aprehensión de la norma, explicite atributos normativos y sustituya la memorización por la creación de imágenes o dibujos.

Por otro lado, se sugiere el desarrollo de imágenes que permitan caracterizar el mal contable o lo que hacen mal los contadores en su ejercicio profesional, de este modo, con la unión de los esquemas y las imágenes, desarrollar aprendizajes sobre las conductas sancionadas que el profesional en formación y el recién egresado deberían evitar con el fin de cumplir su código de ética profesional. Se espera que este análisis descriptivo permita dinamizar discusiones académicas que conduzcan a comprender las razones por las cuales fallan los contadores públicos y conlleve a propuestas 
que propendan por mejorar la manera como se forman en ética profesional. También establecer un problema central como el del "mal contable" en Colombia, que debe ser atendido por los investigadores contables y académicos que procuran por un ejercicio profesional que responda a la verdad y a la honestidad en el ejercicio profesional.

\section{REFERENCIAS BIBLIOGRÁFICAS}

Bedoya, M. y Aparicio, M. (2013). Análisis descriptivo de las conductas que vulneran el código de ética del contador público según las sanciones emitidas por la Junta Central de Contadores Públicos entre los años 2010 a 2013. Universidad Autónoma de Occidente. Trabajo de grado.

Consejo Técnico de la Contaduría Pública.

Presentación. Impactos de la aplicación del Decreto 302 del 2015 en el ejercicio de la profesión contable. Conceptos Básicos. José Hernández. Socio Grant Thornton Fast \& ABS Auditores. Recuperado de http:// www.ctcp.gov.co/_files/documents/ DOC_CTCP_ZQCDT_185.pdf

Decreto 302 de 2015. Diario oficial, 20 de febrero del 2015. Apartado: Código de Ética para Profesionales de la Contabilidad.

García, M. (2003). Los escándalos financieros y la auditoria. Pérdida y recuperación de la confianza en una profesión en crisis. Revista Valenciana de Economía y Hacienda, (7), pp. 25-48.

IESBA. (2014). Manual del Código de ética para profesionales de la Contabilidad. IFAC.
Junta Central de Contadores. (2012). Acuerdo 15 (18 de octubre del 2012). Por el cual se adopta la guía general para el trámite de los procesos disciplinarios de competencia del tribunal disciplinario de la Junta Central de Contadores. Diario Oficial. Bogotá.

Junta Central de Contadores. (2017). Informe de gestión presidente tribunal disciplinario. Periodo abril 2016 - mayo 2017. Recuperado de http://www.jcc. gov.co/images/pdfs/Noticias_2017/ Presentaci\%C3\%B3N_INFORME_FINAL_PRESIDENTE_TD-2.pdf

Junta Central de Contadores. (2018). Informe de gestión, vigencia 2017.

Ley 43 (13 de diciembre de 1990). Estatuto de la profesión del contador público. Diario Oficial. Bogotá.

Ley 599 (24 de julio del 2000). Por la cual se expide el código penal. Diario Oficial. Bogotá.

Molano, C. (14 de marzo del 2017). Panel - contaduría pública y corrupción: perspectivas y retos.

Nieto, A. (2017). Análisis de las faltas de ética de los contadores y revisores fiscales en los fraudes. Estudio de caso: desfalco a la DIAN. (Tesis inédita de maestría). Universidad Nacional de Colombia, Bogotá. Recuperado de http://bdigital.unal.edu.co/59815/1/ An\%C3\%A1lisis\%20de\%20las\%20 faltas $\% 20 \% \mathrm{C} 3 \%$ A 9 ticas $\% 20 \mathrm{de} \% 20$ los $\% 20$ contadores $\% 20 y \% 20$ revisores $\% 20$ fiscales $\% 20$ en $\% 2010$ os $\% 20$ fraudes.pdf

Ochoa, L., Zamarra, J. y Guevara, J. (2011). ¿Cuál ha sido la responsabilidad de la auditoría en los escándalos financieros? Revista Contaduría Universidad de Antioquia, (58-59), 117-145. 
Universidad Libre. (2018). 504 contadores públicos han sido sancionados por casos de corrupción, revela informe. Recuperado de http://www.unilibre. edu.co/bogota/ul/noticias/noticiasuniversitarias/3417-504-contadorespublicos-han-sido-sancionados-porcasos-de-corrupcion-revela-informe

\section{ANEXO}

El desarrollo de los esquemas normativos sigue las siguientes reglas de construcción:

a. Una palabra del texto normativo se representa mediante las dos primeras letras de esta. Ejemplo: beneficio, se expresa con el símbolo: "be".

b. Dos palabras que se entienden unidas en el texto normativo se representan mediante la primera letra de cada una de las palabras. Ejemplo: beneficio económico, se expresa con el símbolo: "be".

c. Tres palabras que se entienden unidas en el texto normativo se representan mediante la primera letra de cada una de las palabras. Ejemplo: beneficio económico futuro, se expresa con el símbolo: "bef".

d. En un mismo esquema no se puede utilizar el mismo símbolo para sentidos distintos. Por ejemplo, las palabras información e ingresos, se pueden ex- presar con el símbolo "in", en diferentes esquemas, pero en un mismo esquema se requiere una tercera letra para diferenciar cada símbolo, por ejemplo, "in" para información, e "ing" para ingreso.

e. Entre más simple es mejor: se debe elaborar una imagen simple del texto normativo, que incluya los elementos de la norma y que al final de verla se sienta que se está leyendo la norma.

f. Se debe procurar elaborar un dibujo con secuencia y movimiento, por ejemplo, elementos del pasado se pueden representar con flechas que surgen detrás de un símbolo, análisis a través del tiempo se pueden simbolizar con flechas que simulan un avance.

g. Solo se usa una sola letra para los símbolos de carácter aritmético y lógico, por ejemplo: menor se expresa con "<", diferente se expresa con " $\neq$ ", negación se expresa con "-".

h. Cada esquema involucra conectores y corchetes cuyo significado se debe estipular.

i. Una vez que se desarrolla el esquema, de debe leer de izquierda a derecha, uniendo los símbolos y sus significados según se presentan en la tabla de símbolos. El esquema será adecuado si logra capturar el contenido normativo. 